\title{
Carbon and nitrogen status of decomposing roots in three adjacent coniferous plantations
}

\author{
J. Jeong, C. Kim
}

\begin{abstract}
Jeong J., Kim C., 2014. Carbon and nitrogen status of decomposing roots in three adjacent coniferous plantations. Ann. For. Res. 57(1): 109-117, 2014.

Abstract. This study evaluated the carbon (C) and nitrogen (N) status of decomposing roots in three adjacent plantations consisting of one deciduous (larch: Larix leptolepis) and two evergreen (red pine: Pinus densiflora; rigitaeda pine: $P$. rigitaeda) species planted in the same year (1963) under similar site conditions. The mass loss rates and $\mathrm{C}$ and $\mathrm{N}$ status of three diameter classes of roots (UF $<2 \mathrm{~mm}$, F $2-5 \mathrm{~mm}$, CF $5-10 \mathrm{~mm}$ in diameter) were examined in the upper $15 \mathrm{~cm}$ of the mineral soil using in situ buried root bags for 496 days. The remaining mass of decomposing roots was significantly higher for larch $(69.0 \%)$ than for red pine $(59.6 \%)$ or rigitaeda pine $(59.1 \%)$ over 496 days. The mass loss rates of decomposing roots did not differ significantly among the three root diameter classes, but the $\mathrm{C}$ and $\mathrm{N}$ status of decomposing roots was affected by the tree species. The larch roots showed low $\mathrm{C}$ concentrations but high $\mathrm{N}$ concentrations, $\mathrm{C}$ and $\mathrm{N}$ remaining compared to the pine roots over the study period. The results indicate that the substrate quality indicators of roots were not attributed to the mass loss rates, $\mathrm{C}$ and $\mathrm{N}$ status of decomposing roots in three coniferous tree species grown under similar environmental conditions. Keywords carbon cycling, fine roots, root mass loss, nitrogen, nutrient, root turnover.
\end{abstract}

Authors. Jaeyeob Jeong - CERAR, CRC-CARE, University of South Australia, Mawson Lake Campus, Adelaide, SA 5095, Australia, Choonsig Kim (ckim@) gntech.ac.kr) - Department of Forest Resources, Gyeongnam National University of Science and Technology, Jinju 660-758, Republic of Korea.

Manuscript received January 16, 2014; revised March 10, 2014; accepted March 17, 2014; online first April 11, 2014.

\section{Introduction}

Belowground organic carbon $(\mathrm{C})$ and nutrient stocks in forest stands can be influenced by root decomposition processes (Cairns et al. 1997, Jackson et al. 1997, Silver \& Miya
2001). However, root decomposition rates are affected by biotic factors, such as decomposer organisms present in the soil (King et al. 1997, Silver \& Miya 2001, Mao et al. 2011), by abiotic factors, such as soil temperature, soil moisture and nitrogen availability; and by for- 
est management activities, such as fertilization and thinning (Silver \& Miya 2001, King et al. 2002). In addition, tree species can influence $C$ and nitrogen $(\mathrm{N})$ inputs from roots because the root litter produced by different species differs in quantity and quality of substrate (Sakai et al. 2007, Mao et al. 2011). Thus, the balance between roots and their decomposition controls the development of soil organic matter and the soil C and N content (Silver \& Miya 2001). The root decomposition rates of different tree species show no consistent patterns. For example, one study found that root decomposition rates were faster in broadleaved trees than in coniferous species (Silver \& Miya 2001), but another study found that the rates were higher in pine roots than in oak roots with high calcium concentrations (Kim 2002). In addition, it is not easy to compare root decomposition rates of different tree species due to the potentially confound effects of site environmental and forest management factors.

Red pine (Pinus densiflora), rigitaeda pine ( $P$. rigitaeda), and larch (Larix leptolepis) are the three most important coniferous tree species planted throughout Korea during the last forty years (Korea Forest Service 2010). Information is needed to evaluate the direction and rates of change in $\mathrm{C}$ and $\mathrm{N}$ status from decomposing roots because the role of belowground litter decomposition, such as root decomposition, is poorly understood in various plantation types in Korea. Although numerous studies have evaluated the effects of forest types on root decomposition (Chen et al. 2002, Kim 2002, Mao et al. 2011), major uncertainties remain about the importance and behavior of $\mathrm{C}$ and $\mathrm{N}$ status during root decomposition in coniferous plantations. In addition, few root decomposition studies have measured the decay rates and nutrient dynamics of tree species in Korea (Kim 2002, Pyo et al. 2002). The objectives of this study were to quantify the root decomposition rates and $\mathrm{C}$ and $\mathrm{N}$ status for roots of various diameter classes in larch and pine plantations under similar site environmental conditions.

\section{Materials and methods}

The study was conducted in the Sambong National Exhibition Forest administered by Korea Forest Service, which is located in Hamyanggun, Gyeongsangnamdo. The mean annual precipitation in this area is $1,322 \mathrm{~mm}$, and the mean annual temperature is $12.8^{\circ} \mathrm{C}$. The experimental plantations, consisting of one deciduous (larch) and two evergreen coniferous species (red pine, rigitaeda pine), are located adjacent to each other (Table 1). All three plantations were established in 1963 on northeast facing slopes $\left(5-15^{\circ}\right)$. The study sites have identical macroclimatic conditions and plantation ages. More information about soil, understory vegetation and litter fall of this study site can be found elsewhere (Kim et al. 2010).

Data were collected from three $20 \mathrm{~m} \times 10$

Table 1 General stand characteristics of three coniferous plantations

\begin{tabular}{|c|c|c|c|c|c|}
\hline Plantation & Location & $\begin{array}{l}\text { Elevation } \\
(\mathrm{m})\end{array}$ & $\begin{array}{l}\text { Stand density } \\
\left(\text { trees } h^{-1}\right)\end{array}$ & $\begin{array}{l}\mathrm{DBH} \\
(\mathrm{cm})\end{array}$ & $\begin{array}{l}\text { Basal area } \\
\left(\mathrm{m}^{2} \mathrm{ha}^{-1}\right)\end{array}$ \\
\hline L. leptolepis & $\begin{array}{l}35^{\circ} 27^{\prime} 26^{\prime \prime} \mathrm{N} \\
127^{\circ} 38^{\prime} 30^{\prime \prime} \mathrm{E}\end{array}$ & 674 & $\begin{array}{l}350 \\
(300-400)\end{array}$ & $\begin{array}{l}31.1 \\
(27.2-36.5)\end{array}$ & $\begin{array}{l}27.6 \\
(18.1-35.6)\end{array}$ \\
\hline P. densiflora & $\begin{array}{l}35^{\circ} 27^{\prime} 28^{\prime \prime} \mathrm{N} \\
128^{\circ} 38^{\prime} 27^{\prime \prime} \mathrm{E}\end{array}$ & 684 & $\begin{array}{l}216 \\
(200-250)\end{array}$ & $\begin{array}{l}34.8 \\
(31.3-36.3)\end{array}$ & $\begin{array}{l}20.7 \\
(19.7-21.3)\end{array}$ \\
\hline P. rigitaeda & $\begin{array}{l}35^{\circ} 27^{\prime} 27^{\prime \prime} \mathrm{N} \\
128^{\circ} 38^{\prime} 31^{\prime \prime} \mathrm{E}\end{array}$ & 678 & $\begin{array}{l}550 \\
(450-650)\end{array}$ & $\begin{array}{l}29.4 \\
(28.5-30.3)\end{array}$ & $\begin{array}{l}35.8 \\
(29.9-41.3)\end{array}$ \\
\hline
\end{tabular}

Note. Values in parentheses represent ranges. $\mathrm{N}=3$ plots per species. $\mathrm{DBH}$ : diameter at breast height $(1.3 \mathrm{~m})$. 
$\mathrm{m}$ plots within each plantation. The plots were within a distance of $<20 \mathrm{~m}$ between plantations to reduce sampling bias of site components. The mean stand density, diameter at breast height (DBH), and basal area of each plantation are shown in Table 1 . The difference of stand density and basal area among the three coniferous plantations was attributed to the common silvicultural practices such as thinning.

Root decomposition rates were estimated using in situ buried root decay bags $(15 \mathrm{~cm}$ $\times 15 \mathrm{~cm}$, with a $0.5 \mathrm{~mm}$ mesh size), the most commonly used technique for comparing root decay rates (Silver \& Miya 2001, Yang et al. 2004, Lin et al. 2011). In each plantation, fresh roots were collected from a randomly located sampling point at a depth of approximately 15 $\mathrm{cm}$ in the mineral soil on July 15, 2006. For this study, the root system was divided into woody and non-woody roots $<2 \mathrm{~mm}$ (UF), 2$5 \mathrm{~mm}(\mathrm{~F})$ and 5-10 $\mathrm{mm}(\mathrm{CF})$ in diameter and their associated root tips. After collection, the roots were gently rinsed with tap water, sorted into size classes, and air dried to constant mass at room temperature for 20 days. Root samples with an air dried mass of $1 \mathrm{~g}$ were weighed to the nearest $0.01 \mathrm{~g}$ and placed in numbered bags. Subsamples from each root type were also taken to determine their mass after oven drying at $65^{\circ} \mathrm{C}$ for $48 \mathrm{~h}$.

27 root bags ( 3 plots $\times 3$ root diameter size classes $\times 3$ replication) were incubated in the mineral soil layer of each plantation. On 29 July 2006, the bags were inserted vertically into the mineral soil to a depth of $15 \mathrm{~cm}$ using a straight blade shovel. The bags were collected after 496 days of incubation (7 December 2007). The collected bags were oven dried at $65^{\circ} \mathrm{C}$ for $48 \mathrm{~h}$, cleaned by gentle brushing with a soft paintbrush to remove the mineral soil, and weighed to determine root mass loss rates. All root samples were ground in a mortar to pass a $0.04 \mathrm{~mm}$ mesh. An elemental analyzer (Thermo Scientific, Flash 2000, Italy) was used to quantify $\mathrm{C}$ and $\mathrm{N}$ concentration in the ground materials. The $\mathrm{C}$ and $\mathrm{N}$ remaining in the bags was estimated by multiplying mass of non-decomposed roots and $\mathrm{C}$ or $\mathrm{N}$ concentration.

To evaluate the relationship between root decomposition and soil environmental factors, soil samples by using an Oakfield soil sampler from each plot were collected monthly during the study period at a depth of $20 \mathrm{~cm}$. The soil core samples were placed in plastic bags, transported to the laboratory and oven dried at $105^{\circ} \mathrm{C}$ for $48 \mathrm{~h}$ to quantify the soil gravimetric water content. Soil temperature was measured at a depth of $20 \mathrm{~cm}$ adjacent to the soil collection sites using a soil temperature probe. Soil $\mathrm{pH}$ (1:5 soil:water) was measured using a glass electrode.

A two way ANOVA was used to examine the main and interaction effects of tree species and root diameter size classes using general linear models in SAS (SAS Institute Inc. 2003) to determine the significance of treatments at $P$ $<0.05$. The assumption for a parametric test was examined by homogeneity of variances by the Hartley test and normal probability plots before performing the ANOVA (Milliken \& Johnson 2002). Where appropriate, treatment means were compared using Tukey's test.

\section{Results}

\section{Mass loss rates of decomposing roots}

The three coniferous tree species showed a significant difference in root decomposition rates (Table 2). The remaining mass of decomposing roots were significantly higher for larch $(69.0 \%)$ than for red pine $(59.6 \%)$ or rigitaeda pine (59.1\%) after 496 days (Table 3). The remaining mass of decomposing roots was not significantly different among root diameter classes with no interaction effects (Table 2, 3). Soil environmental factors such as soil temperature, soil water content and soil $\mathrm{pH}$ were significantly lower in the larch than in the red 
Table 2 ANOVA results for root diameter classes in three coniferous plantations

\begin{tabular}{lllc}
\hline Component & Variable & $\begin{array}{l}\text { 29 Jul. 2006 } \\
\text { (initial incubation) }\end{array}$ & $\begin{array}{c}\text { 7 Dec. 2007 } \\
\text { (after 496 days) }\end{array}$ \\
\hline Mass remaining & Tree species (T) & - & $<\mathbf{0 . 0 0 0 1}$ \\
& Root diameter (R) & - & 0.1737 \\
& $\mathrm{~T} \times \mathrm{R}$ & - & 0.1148 \\
\hline C concentration & Tree species $(\mathrm{T})$ & $\mathbf{0 . 0 0 0 4}$ & $\mathbf{0 . 0 3 1 8}$ \\
& Root diameter $(\mathrm{R})$ & $<\mathbf{0 . 0 0 0 1}$ & $\mathbf{0 . 0 0 0 1}$ \\
& $\mathrm{T} \times \mathrm{R}$ & $<\mathbf{0 . 0 0 0 1}$ & 0.2640 \\
\hline N concentration & Tree species $(\mathrm{T})$ & $<\mathbf{0 . 0 0 0 1}$ & 0.3693 \\
& Root diameter $(\mathrm{R})$ & $<\mathbf{0 . 0 0 0 1}$ & $<\mathbf{0 . 0 0 0 1}$ \\
& $\mathrm{T} \times \mathrm{R}$ & $<\mathbf{0 . 0 0 0 1}$ & $\mathbf{0 . 0 1 7 4}$ \\
\hline C/N ratio & Tree species $(\mathrm{T})$ & $<\mathbf{0 . 0 0 0 1}$ & 0.2743 \\
& Root diameter $(\mathrm{R})$ & $<\mathbf{0 . 0 0 0 1}$ & $<\mathbf{0 . 0 0 0 1}$ \\
& $\mathrm{T} \times \mathrm{R}$ & $\mathbf{0 . 0 0 4 5}$ & $\mathbf{0 . 0 0 6 6}$ \\
\hline C remaining & Tree species $(\mathrm{T})$ & $\mathbf{0 . 0 0 0 4}$ & $<\mathbf{0 . 0 0 0 1}$ \\
& Root diameter $(\mathrm{R})$ & $<\mathbf{0 . 0 0 0 1}$ & $\mathbf{0 . 0 0 1 2}$ \\
& $\mathrm{T} \times \mathrm{R}$ & $<\mathbf{0 . 0 0 0 1}$ & $\mathbf{0 . 0 0 2 5}$ \\
\hline N remaining & Tree species $(\mathrm{T})$ & $<\mathbf{0 . 0 0 0 1}$ & $\mathbf{0 . 0 1 9 1}$ \\
& Root diameter $(\mathrm{R})$ & $<\mathbf{0 . 0 0 0 1}$ & $\mathbf{0 . 0 0 1 0}$ \\
& $\mathrm{T} \times \mathrm{R}$ & 0.0701 \\
\hline
\end{tabular}

Note. Bold values denote significance at $P<0.05$.

Table 3 Mean percentage of mass remaining of decomposing roots of three diameter classes (UF $<2 \mathrm{~mm}$, F 2-5 mm, CF 5-10 mm in diameter) from 29 Jul. 2006 (initial incubation) to 7 Dec. 2007 (after 496 days) in three coniferous plantations.

\begin{tabular}{ll}
\hline Treatment & Mass remaining (\%) \\
\hline Tree species & \\
L. leptolepis & $69.0(2.4)^{\mathrm{a}}$ \\
P. densiflora & $59.6(3.9)^{\mathrm{b}}$ \\
P. rigitaeda & $59.1(3.9)^{\mathrm{b}}$ \\
\hline Root diameter & \\
CF & $65.3(3.38)^{\mathrm{a}}$ \\
F & $61.4(3.28)^{\mathrm{a}}$ \\
UF & $61.9(2.64)^{\mathrm{a}}$ \\
\hline
\end{tabular}

Note. Values in parentheses indicate two standard errors. Treatment means followed by the same letter are not significantly different at $P<0.05$.

pine or rigitaeda pine during the study period (Figure 1).

\section{C and $\mathbf{N}$ status of decomposing roots}

There was a significant interaction effect in the initial root $\mathrm{C}$ concentration (Table 2, Figure 2 ). The $\mathrm{C}$ concentration of UF roots in larch 112 showed significantly lower concentrations compared to $\mathrm{CF}$ in other two pine species. The root $\mathrm{C}$ concentrations after 496 days differed significantly among tree species and root diameter classes with no interaction effects (Table 2). The $\mathrm{C}$ concentration was significantly lower in the red pine roots $\left(462 \mathrm{~g} \mathrm{~g}^{-1}\right)$ than in the larch $\left(478 \mathrm{~g} \mathrm{~g}^{-1}\right)$ or rigitaeda pine $\left(479 \mathrm{~g} \mathrm{~g}^{-1}\right)$ 
roots (Figure 2). Also, UF (458 $\left.\mathrm{g} \mathrm{g}^{-1}\right)$ and $\mathrm{F}$ $\left(470 \mathrm{~g} \mathrm{~g}^{-1}\right)$ roots showed significantly lower C concentrations compared to $\mathrm{CF}\left(490 \mathrm{~g} \mathrm{~g}^{-1}\right)$ after 496 days (Figure 2). The initial root $\mathrm{N}$ concentration was significantly higher for larch than for rigitaeda pine and red pine. The concentration was also significantly higher in UF $(12.0 \mathrm{~g}$ $\left.\mathrm{g}^{-1}\right)$ than in $\mathrm{F}\left(8.0 \mathrm{~g} \mathrm{~g}^{-1}\right)$ or $\mathrm{CF}\left(9.0 \mathrm{~g} \mathrm{~g}^{-1}\right)$ roots (Figure $3 \mathrm{~A}$ ). The initial $\mathrm{C} / \mathrm{N}$ ratio was the lowest in larch (43.8), followed by rigitaeda pine (50.5) and red pine (55.0) roots (Figure 3B). The $\mathrm{C}$ remaining of decomposing roots decreased rapidly in $\mathrm{F}$ and $\mathrm{CF}$ roots of both pine species compared to the larch roots during the study period (Figure $3 \mathrm{C}$ ). The $\mathrm{N}$ remaining of

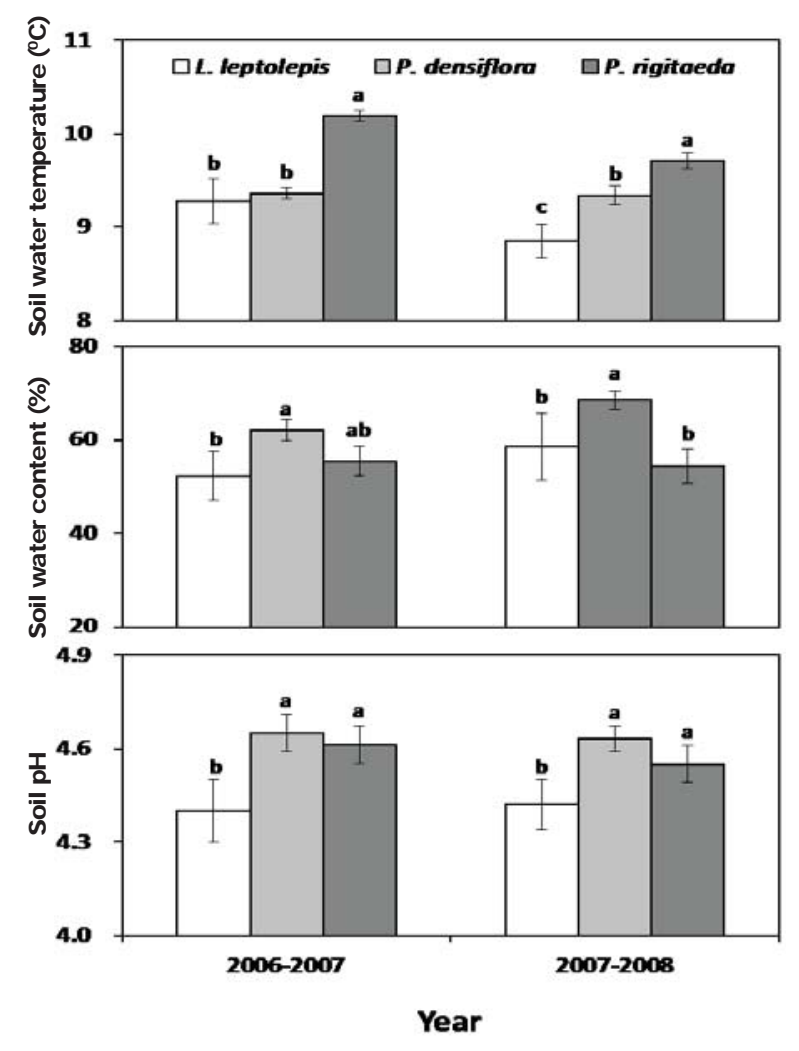

decomposing roots was significantly lower in red pine $\left(4.96 \mathrm{mg} \mathrm{bag}^{-1}\right)$ than in larch $(5.72 \mathrm{mg}$ bag $\left.^{-1}\right)$, and decreased in F $\left(5.05 \mathrm{mg} \mathrm{bag}^{-1}\right)$ and CF (5.0 mg bag $\left.{ }^{-1}\right)$ roots compared to UF (5.93 $\mathrm{mg} \mathrm{bag}^{-1}$ ) roots (Figure 4).

\section{Discussion}

\section{Mass loss rates of decomposing roots}

The mass loss rates of decomposing roots were significantly affected by the three coniferous tree species. Root decomposition rates can be influenced by abiotic factors, such as soil
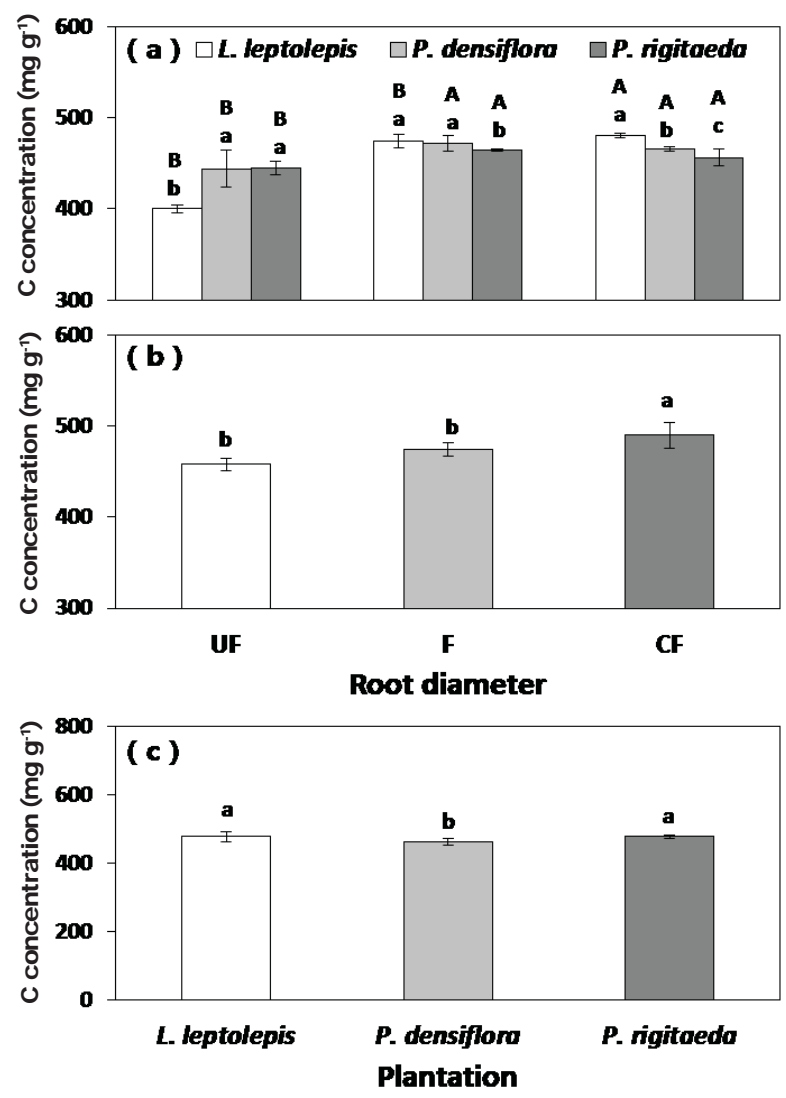

Figure 1 Annual mean soil temperature, soil water content, and soil $\mathrm{pH}$ in three coniferous plantations. Ver(left) tical bars indicate two standard errors. Treatment means with the same letter among tree species are not significantly different at $P<0.05$.

Figure 2Changes in carbon concentrations of decomposing roots of three diameter classes (UF: $<2 \mathrm{~mm}$; F: (right) 2-5 mm; CF: 5-10 mm in diameter) in three coniferous plantations (a: Jul. 2006; b: Dec. 2007; c: Dec. 2007). Vertical bars indicate two standard errors. Treatment means with the same lower case letter among tree species and treatment means with the same upper case letter among root diameter classes are not significantly different at $P<0.05$. 


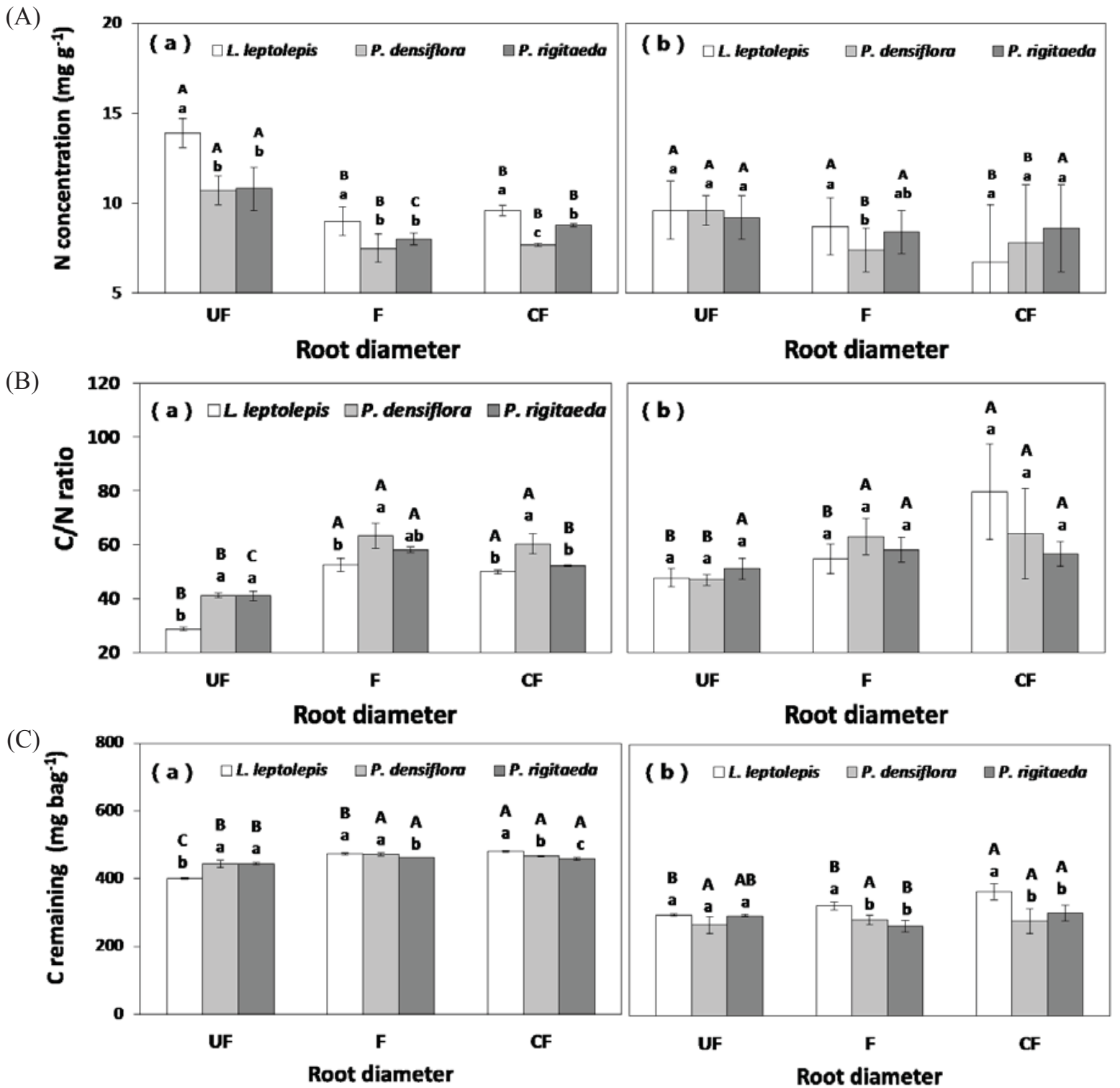

Figure 3 Changes in the nitrogen concentrations (top), $\mathrm{C} / \mathrm{N}$ ratios (middle), $\mathrm{C}$ remaining (botton) of decomposing roots of three diameter classes (UF $<2 \mathrm{~mm}$, F 2-5 mm, CF $5-10 \mathrm{~mm}$ in diameter) in three coniferous plantations (a. Jul. 2006, b. Dec. 2007). Vertical bars indicate two standard errors. Treatment means with the same lower case letter among tree species and treatment means with the same upper case letter among root diameter classes are not significantly different at $P<0.05$

temperature, soil moisture and nitrogen availability, and by biotic factors, such as the decomposer organisms present in the soil and the lignin concentration of the plant litter (Chen et al. 2002, Hobbie et al. 2010). In this study, soil temperature and soil water content, which are regarded as the main abiotic factors influencing root decomposition, differed significantly among the three coniferous tree species. For example, soil temperature, which strongly affects the soil microbial community or nutrient availability, was significantly higher in the red pine plantation than in the larch plantation (Figure 1). This result indicates that pine roots may be stimulated by high soil temperatures, which provide favorable environmental 

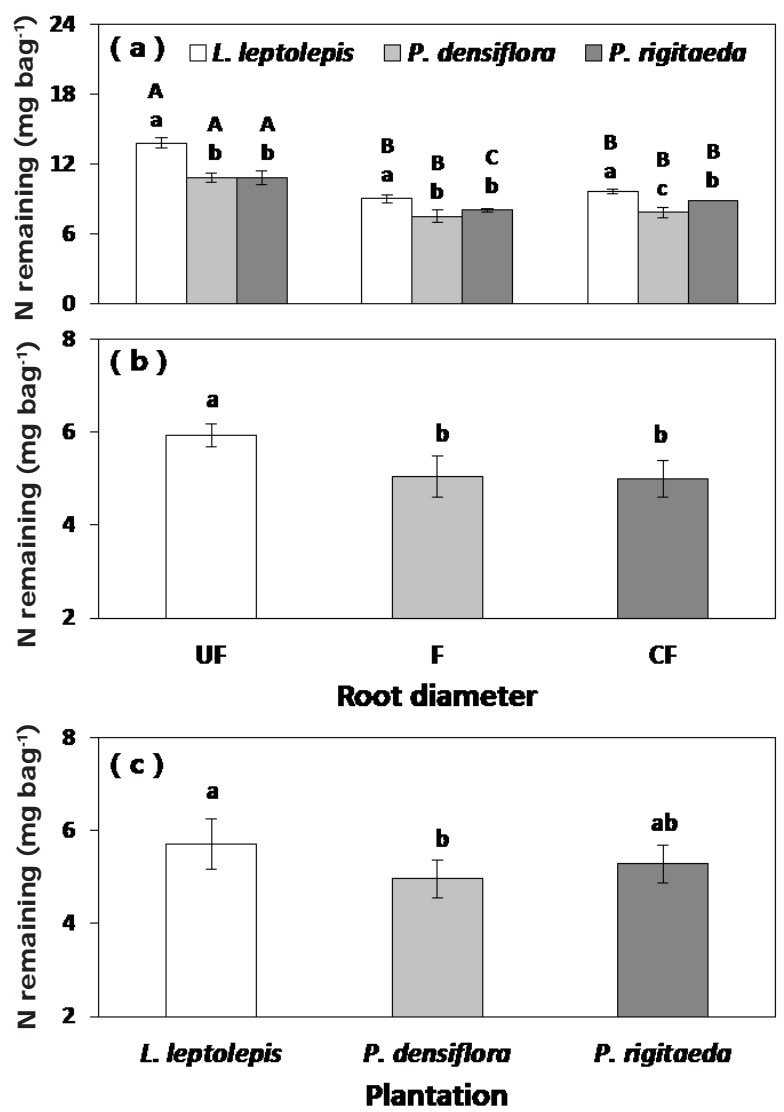

Figure 4 Changes in the $\mathrm{N}$ remaining of decomposing roots of three diameter classes (UF: < $2 \mathrm{~mm}$; F: 2-5 mm; CF: 5-10 $\mathrm{mm}$ in diameter) in three coniferous plantations(a: Jul. 2006; b: Dec. 2007; c: Dec. 2007). Vertical bars indicate two standard error. Treatment means with the same lower case letter among tree species and treatment means with the same upper case letter among root diameter classes are not significantly different at $P<0.05$.

conditions for the activity of soil microflora and fauna among the three coniferous species. Other studies have reported that mass loss of decomposing roots may be attributed to differences in substrate quality (Lin et al. 2011, Mao et al. 2011), substantial leaching loss of soluble and labile $\mathrm{C}$ components during the early stages of decomposition (Ludovivi \& Kress 2006), ectomycorrhizal colonization (Koide et al. 2011), or soil environmental factors (Chen et al. 2002). In addition, ectomycorrhizal colonization significantly retarded the decomposition of $P$. edulis roots (Langley et al. 2006) but did not significantly affect the decomposition of $P$. resinosa roots (Koide et al. 2011). This discrepancy was explained by the significant variation in ectomycorrhizal colonization among tree species (Koide et al. 2011). However, little is known about the in situ ectomycorrhizal colonization of larch and pine roots in Korea.

Many studies have reported that roots with high $\mathrm{N}$ concentrations and low $\mathrm{C} / \mathrm{N}$ ratios decompose more rapidly than those with low $\mathrm{N}$ concentrations and high $\mathrm{C} / \mathrm{N}$ ratios because the initial $\mathrm{C} / \mathrm{N}$ ratio is the most widely used index of root substrate quality (Usman et al. 2000, Silver \& Miya 2001, Lin et al. 2011). However, the mass loss of larch roots in this study was not related to a higher $\mathrm{N}$ concentration or lower $\mathrm{C} / \mathrm{N}$ ratio compared to pine roots (Figure $3 \mathrm{a}, 3 \mathrm{~b}$ ) because the initial $\mathrm{C} / \mathrm{N}$ ratio was significantly lower for larch than for rigitaeda pine or red pine, despite the slower decomposition of larch roots during the study period.

Root decomposition rates increase with decreased root diameter because smaller roots have higher $\mathrm{N}$ concentrations and therefore decompose faster compared to larger roots (King 1997, Usman et al. 2000). However, there are no consistent relationships between root decomposition rates and $\mathrm{N}$ concentrations because large roots decomposed more rapidly than smaller roots despite their low $\mathrm{N}$ concentrations (Lin et al. 2011). High N concentrations in smaller roots may stimulate the formation of relatively stable $\mathrm{N}$ lignin complexes (Lin et al. 2011, Mao et al. 2011,). Similarly, initial root $\mathrm{N}$ concentration in small roots was not correlated with fine root decomposition rates in coniferous forests in the Pacific Northwest, USA (Chen et al. 2002). The lack of a relationship between root size and mass loss rates in this study could be due to complex ecosystem level responses to the changes in soil environmental factors (Figure 1) caused by different tree species (King et al. 1997, Chen et al. 2002). Other studies have reported that 
root decomposition in loblolly pine is partially correlated with $\mathrm{N}$ concentration and root size class early in the incubation process (Fahey \& Arthur 1994, King 1997).

\section{$\mathrm{C}$ and $\mathbf{N}$ status of decomposing roots}

The root $\mathrm{C}$ concentration was differed significantly among species and root diameter classes. The intra specific variation of $\mathrm{C}$ concentration in tree species is determined by genetic and environmental factors such as site conditions, stand characteristics and forest management practices (Elias \& Potvin 2003, Bert \& Danjon 2006). The mean initial C concentrations (451$461 \mathrm{~g} \mathrm{~g}^{-1}$ ) reported here are comparable to the mean $\mathrm{C}$ concentration of $461 \mathrm{~g} \mathrm{~g}^{-1}$ roots for the fine roots of 15 coniferous tree species in the Pacific Northwest, USA (Chen et al. 2002) and were lower than for the $\mathrm{C}$ concentration $(474 \mathrm{~g}$ $\mathrm{g}^{-1}$ ) of $P$. laeformis in China (Mao et al. 2011). The $\mathrm{C}$ concentration differed significantly among root diameter classes during the study period. A previous study found that roots $<2$ $\mathrm{mm}$ in diameter contained less $\mathrm{C}$ than larger roots (Gordon \& Jackson 2000) because soft tissues, such as those found in fine roots, have low $\mathrm{C}$ concentration compared to woody tissues, such as coarse roots (Kraenzel et al. 2003). The $\mathrm{C}$ remaining in decomposing roots decreased rapidly in $\mathrm{F}$ and $\mathrm{CF}$ roots of both pine species compared to larch roots during the study period. The $\mathrm{C}$ release of each root diameter class was approximately proportional to the mass loss of the roots. The $\mathrm{C}$ remaining over the study period did not exceed the initial $\mathrm{C}$ content of the roots.

The initial root $\mathrm{N}$ concentration in three root diameter classes was significantly higher for the larch than for the rigitaeda pine and red pine roots. The higher $\mathrm{N}$ concentration of the larch roots compared to the two types of pine roots may be due to the inherently high $\mathrm{N}$ uptake of the deciduous larch compared to evergreen pine species (Finzi et al. 1998). However, the low $\mathrm{N}$ concentration in large roots may be due to an increasing proportion of lignified woody components. The observed $\mathrm{N}$ values $\left(9.0 \mathrm{~g} \mathrm{~g}^{-1}-12.0 \mathrm{~g} \mathrm{~g}^{-1}\right)$ in this study were higher than the mean $\mathrm{N}$ concentration $(<2 \mathrm{~mm}, 9.4$ $\left.\mathrm{g} \mathrm{g}^{-1} ; 2-5 \mathrm{~mm}, 5.9 \mathrm{~g} \mathrm{~g}^{-1} ;>5 \mathrm{~mm}, 4.5 \mathrm{~g} \mathrm{~g}^{-1}\right)$ reported for each root diameter class on a global scale (Silver \& Miya 2001). The N remaining of decomposing roots was significantly lower in red pine than in larch and decreased in $\mathrm{F}$ and $\mathrm{CF}$ roots compared to UF roots. The $\mathrm{N}$ remaining of decomposing roots followed the pattern of $\mathrm{N}$ concentration (Figure $3 \mathrm{~A}$ ) and $\mathrm{C}$ remaining (Figure $3 \mathrm{C}$ ) with no $\mathrm{N}$ absorption in any diameter classes of roots observed throughout the decomposition process.

\section{Conclusions}

The mass loss rates in the three coniferous tree species were relatively weakly influenced by substrate quality indicators, such as the $\mathrm{N}$ concentration and $\mathrm{C} / \mathrm{N}$ ratio, but were linked to differences in soil temperature and soil $\mathrm{pH}$ among the tree species. The mass loss rates of decomposing roots did not differ significantly among the three root diameter classes, but the $\mathrm{C}$ and $\mathrm{N}$ status of decomposing roots was affected by the tree species. The larch roots showed low $\mathrm{C}$ concentration but high $\mathrm{N}$ concentration, $\mathrm{C}$ and $\mathrm{N}$ remaining compared to the pine roots. These results indicate that the mass loss and $\mathrm{C}$ and $\mathrm{N}$ status of decomposing roots differed considerably between a deciduous larch and two evergreen pine plantations.

\section{Acknowledgements}

This study was carried out with the partial support of "Forest Science \& Technology Projects (Project No. S211212L030320)" provided by Korea Forest Service and Gyeongnam National University of Science and Technology (2013). 


\section{References}

Bert D., Danjon D., 2006. Carbon concentration variations in the roots, stem and crown of mature Pinus pinaster (Ait.). Forest Ecology and Management 222: 279-295. DOI: 10.1016/j.foreco.2005.10.030.

Chen H., Harmon M.E., Sexton J., Fasth B., 2002. Fineroot decomposition and $\mathrm{N}$ dynamics in coniferous forests of the Pacific Northwest, U.S.A. Canadian Journal of Forest Research 32: 320-331. DOI: 10.1139/x01202.

Elias M., Potvin C., 2003. Assessing inter- and intra-specific variation in trunk carbon concentration for 32 neotropical tree species. Canadian Journal of Forest Research 33: 1039-1045. DOI: 10.1139/x03-018.

Gordon W.S., Jackson R.B., 2000. Nutrient concentrations in fine roots. Ecology 81: 275-280. DOI: 10.1890/00129658(2000)081[0275:NCIFR]2.0.CO;2.

Fahey T.J., Arthur M.A., 1994. Further studies of root decomposition following harvest of a northern hardwoods forest. Forest Science 40: 618-629.

Hobbie S.E., Oleksyn J., Eissenstat D.M., Reich P.B., 2010. Fine root decomposition rates do not mirror those of leaf litter among temperate tree species. Oecologia 162: 505-513. DOI: 10.1007/s00442-009-1479-6.

King J.S., Allen H.L., Dougherty O., Strain B.R., 1997. Decomposition of roots in loblolly pine: Effects of nutrient and water availability and root size class on mass loss and nutrient dynamics. Plant and Soil 195: 171184. DOI: $10.1023 / \mathrm{A}: 1004248232450$.

Kim C., 2002. Mass loss rates and nutrient dynamics of decomposing fine roots in a sawtooth oak and a Korean pine stands. Korean Journal of Ecology 25: 235-240. DOI: 10.5141/JEFB.2002.25.4.235.

Kim C., Jeong J., Cho H.S., Son Y. 2010. Carbon and nitrogen status of littefall, litter decomposition and soil in even-aged larch, red pine and rigitaeda pine plantations. Journal of Plant Research 123: 411-419. DOI: 10.1007/ s10265-010-0317-6.

Koide R., Fernandez C.W., Peoples M.S., 2011. Can ectomycorrhizal colonization of Pinus resinosa roots affect their decomposition? New Phytologist 191: 508-514. DOI: $10.1111 /$ j.1469-8137.2011.03694.x.

Korea Forest Service. 2010. Statistical yearbook of forestry. Korea Forest Service, Daejeon, 491 p.

Kraenzel M., Castillo A., Moore T., Potvin C., 2003. Carbon storage of harvest-age teak (Tectoan grandis) plan- tations, Panama. Forest Ecology and Management 173: 213-225. DOI: 10.1016/S0378-1127(02)00002-6.

Langley J.A., Chapman S.K., Hungate B.A., 2006. Ectomycorrhizal colonization slows root decomposition: the post-mortem fungal legacy. Ecology Letters 9: 23022312.

Lin C., Yang Y., Guo J., Chen G., Xie J., 2011. Fine root decomposition of evergreen broadleaved and coniferous tree species in mid-subtropical China: dynamics of dry mass, nutrient and organic fractions. Plant and Soil 338: 311-327. DOI: 10.1007/s11104-010-0547-3.

Ludovici K.H., Kress L.W., 2006. Decomposition and nutrient release from fresh and dried pine roots under two fertilizer regimes. Canadian Journal of Forest Research 36: 105-111. DOI: 10.1139/x05-227.

McClaugherty C.A., Aber J.D., Melillo J.H., 1982. The role of fine roots in the organic matter and nitrogen budgets of two forest ecosystem. Ecology 63: 1481-1490. DOI: $10.2307 / 1938874$.

Mao R., Zeng D.H., Li L.J., 2011. Fresh root decomposition pattern two contrasting tree species from temperate agroforestry systems: effects of root diameter and nitrogen enrichment of soil. Plant and Soil 347: 115-123. DOI: $10.1007 /$ s11104-011-0830-y.

Milliken G.A., Johnson D.E., 2002. Analysis of messy data, volume III: Analysis of covariance. Chapman \&Hall/CRC, USA. 605 p.

Pyo J.H., Shin C.H., Namgung J., Kim J.H., Mun H.T., 2002. Weight loss and nutrient dynamics during the decomposition of fine roots. Korean Journal of Ecology 25: 41-44.

Sakai Y., Takahashi M., Tanaka N., 2007. Root biomass and distribution of a Picea-Abies stand and a LarixBetula stand in pumiceous Entisols in Japan. Journal of Forest Research 12: 120-125. DOI: 10.1007/s10310006-0270-3.

SAS Institute Inc., 2003. SAS/STAT Statistical software. Version 9.1. SAS publishing Cary, NC.

Silver W.L., Miya R.K., 2001. Global patterns in root decomposition: comparisons of climate and litter quality effects. Oecologia 129: 407-419.

Usman S., Singh S.P., Rawat Y.S., Bargali S.S., 2000. Fine root decomposition and nitrogen mineralization patterns in Quercus leucotrichophora and Pinus roxburghii forests in central Himalaya. Forest Ecology and Management 131: 191-199. DOI: 10.1016/S03781127(99)00213-3. 